\title{
Analysis of Indian Transport System
}

\author{
Dr. Mahesh Patel \\ K. K. Parekh Commerce College, Amreli, India
}

\begin{abstract}
India is one of the fastest growing economies in Asia and the entire world. Especially in the transport and logistics industry sector, India shows superior growth rates creating enhanced potential for foreign players. The objective of this summary is to identify the market potential as well as the current demand in this sector and to point out the investment perspectives, especially for European players. Certainly, climate change affects these prospects. Hence, this summary exposes the current Indian situation and the main challenges contributing to this. But despite these problems and also resulting from these, India offers a high potential for investments as the current studies have already shown.
\end{abstract}

\section{INTRODUCTION}

Transport in the Republic of India is an important part of the nation's economy. Our country has accepted economy reforms in 1991, since Govt of India as invested huge amount of money for the development of infrastructure within die country i.e why it progressed at a rapid pace, and today there is a wide variety of modes of transport by land, water and air. However, India's relatively low GDP per capita has meant that access to these modes of transport has not been uniform. Even though we know that the transportation facilities are playing vital role in the development of the economy.

\section{Objective}

$>$ 1. To explain the present status of the Indian Transport System.

$>$ 2. To explain the relationship of Indian transport and foreign tread

$>$ 3. To know the importance of transport for the growth of tourism.

$>$ 4. To explain the relationship of Automobile Industry \& Transport

$>$ 5. To know the importance of transport for linking different sectors of the economy.

\section{Research Methodology}

Secondary data has been collected from books, news papers, magazines, internet, etc.

\section{Definition of Transport}

Movement of non-living \& living things from one place to another place is known as transport present status of Indian transport system.

\section{Indian transport system can be divided in to three types}

1. Land transport

2. Water transport

3. Air transport

\section{Land transport}

A Transport which is carried out on the surface of the earth is known as land transport This transport classified into two subheads.

\section{Road Transport. \\ 2. Rail Transport.}

\section{Road Transport}

India has a vast road network of about 3.32 Million KM. of which the National Highways and the State Highways together account for 1,95,000 Km. length. The composition of road traffic has grown from $12 \%$, freight and $31.67 \%$ passenger traffic in $1950-51$ to an estimated $65 \%$ freight and $67 \%$ passenger traffic during the 10th five year plan period. Traffic on the roads is growing at the rate of $7.10 \%$ per annum while the growth in vehicles has been to the tune of $12 \%$ per annum for the past few years. The road network therefore needs to be expanded and strengthened at a very fast pace not only to cater to the increased volume of traffic but also to provide improved accessibility to the far off land.

The Indian road network, the largest in the world aggregating 3.32 million KMS. Consists of.

1. National Highways - $6556 \mathrm{KM}$.

2. State Highways - $128000 \mathrm{KM}$.

3. District Roads - 470000 KM.

4. Rural Roads - 2650000 KM.

The National Highways accounts for about $2 \%$ of the total road network but carry as much as $40 \%$ of the total road traffic in the country National \& State Highways occupying a pre-eminent position as nearly $60 \%$, of the freight $\& 87 \%$ of passenger traffic move on them, i.e why these are very important

\section{Rail Transport}

Indian Railways are the biggest public sector under taking in India, it was introduce in 1853 the first train service started from Mumbai to Thane. Indian Railway is largest in India \& 4th largest in the world. Broad-gauge, Meter-gauge, \& Narrow gauge are the types of Railways services at the end of 2004 the network of Indian Railways was spread over 63281 Route KM. comprising of. 


\section{www.ijtsrd.com}

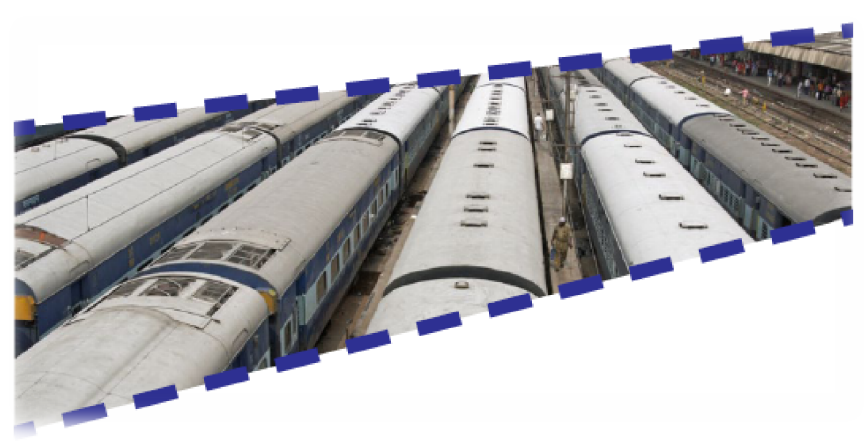

Broad gauge - 46807 Route KM

Meter gauge -13290 Route KM.

Narrow gauge - 3124 Route KM.

Out of which 19000 RKM. is electrified during 2009-10 it carried more than 7200 million passenger's \& about 890million tone $\mathrm{s}$ of train traffic. The freight segment accounts for about $70 \%$ of revenue and passenger $30 \%$ of revenue

\section{Challenges in Transport by Roads}

\section{Natural challenges - Energy}

The transport sector's energy consumption amounts to petroleum products such as gasoline and high speed diesel and depends on the one hand on the modal split and on the other hand on the vehicle speed. Among different modes of transport, buses on average, have the least consumption of energy per passenger-km. For comparison, two wheelers have 2.5 times the consumption of buses and three wheelers 4.8 times that of buses. Furthermore, cars consume on an average, the most energy per passenger-km, i.e. they consume 6 times more energy. This also implies that the fuel costs differ accordingly. For example two-wheelers are 6.8 times costlier than buses. Further, three-wheelers and cars are up to 11 times costlier. Not only does a car use more energy and is therefore costlier, it also takes more road space than buses when providing the same passenger mobility level. Due to the motorization in India an immense pressure on the natural energy resources of India is imposed

\section{Natural challenges - Air Pollution}

The cities in India have to cope with environmental problems due to strong air pollution. The increasing number of fuel using vehicles, lead to increased pollution. The vehicular emissions alone contribute to $72 \%$ of air pollution in total in Delhi and the burning of fossil fuels accounts for about $83 \%$ of the carbon dioxide emissions. The most common particles associated with motorized vehicles polluting the atmosphere are nitrogen oxides, hydrocarbons, carbon monoxide, as wells as sulphur oxides. The air pollution in most Indian cities has become dangerous and has badly influenced the health of the population with regard to diseases in respiration Transport systems and air pollution are directly related whereas the emissions of vehicles depends on different factors such as their speed, age and emission rate.
The Centre of Science and Environment states that that there is a negative correlation between the quantity of the pollutants, above all nitrogen oxide, hydrocarbons and carbon monoxide and the speed of a vehicle. Since the average speed in peak hours is very slow, during these times the air pollution drastically increases.

\section{Industrial/economic barriers}

\section{Fragmentation of Industry}

The fragmented structure even in the organized sector of the road industry and the numerous dominating unorganized operators in this sector, make development and fair competition very difficult. However, small operators depend on other players for handling and marketing, for example: brokers depend on booking agents. The last mentioned group of handlers is the dominant one with the ability to set freight rates. This system increases the price for the end users, leading to low quality of services as well as low profitability for truck operators. More over, because of this fragmentation of the industry, economies of scale can rarely be achieved.

\section{Infrastructure}

Infrastructure is a significant set back in India. Other than on highways, running trucks is only possible for firms using trucks smaller than 20 feet. Hence, the road infrastructure constitutes a major hurdle. For example, for large vehicles such as multi-axle trucks The infrastructure of India's roads is limited and the conditions of the roads make it difficult to have a smooth transportation and operation system.

Therefore, the few but better conditioned national highways are overloaded and filled with the big vehicles lowering the average speed to 10-20 miles per hour.

Further, this leads to more accidents, shorter lifespan of vehicles, an increase in the fuel consumption, higher operating costs caused due to making detours and reduced efficiency. However, the infrastructure investments are merely $4 \%$. Additionally, the difficulties in inter-state movement mentioned above is also hampering the logistics companies, resulting in delays. Thus, the presence of a system of using containerized trucks would be better for logistics because it would fasten the transfers at ports and avoid great thefts at checkpoints.

\section{Labour policy}

The almost non-existing labour policy is yet another barrier in the road transport system.. The drivers of trucks are poorly trained due to lack of formal training institutes for related areas like proper handling etc. and due to a lack of participation in driver training schools. So there is a higher demand in getting a drivers license than the supply of training institutes. Further, the quality and standards of the few existing ones is often not controlled 


\section{Water transport}

A transport facility which is carried on the surface of the water is known as water transport. It can be divided into inland water transport and shipping again divided into coastal shipping, \& overseas shipping. India has about a long coastline of 7517 KMS., 12 Major ports, \& 200 Minor ports, \& vast hinter land, coastal shipping is very energy efficient \& cheapest mode of transport for carrying bulky goods over long distances almost $95 \%$ of India's global merchandise trade is carried through the sea route, India's overseas shipping has improved over the planning period. The country has the largest merchant \& shipping fleet among developing countries \& ranks 23 in the world. As compared to 1.92 million gross tonnage at the time of independence which increased to 10 million gross tonnage in 2008-09. The total traffic carried by the Major ports was about 563 million tones during 2009-10.

\section{Air Transport}

It is the most modem \& fastest mode of transport in India Air transport began to operate in 1920 according to Air Corporation Act 1953, two state corporations were setup namely Air India for international transport \& Indian Airlines for internal transport. In Oct.- 1985. Govt, has setup the Pawanhans Ltd., To provide helicopter base transport service. Since 1991 the civil aviation has opened up to private sector to promote efficiency the private sector is now paying a crucial role in the development of both Airline \& Airport sector it's market share in the domestic traffic during 2006 reached $85 \%$ from near 50\% share earlier jet airlines along with jer life has emerged as the market leader with a share of $26.1 \%$ followed by kingfisher $90 \%$, Indigo $18.7 \%$, Air India (domestic) $15.8 \%$, spice jet $13.8 \%$ \& Go air $6.6 \%$.

\section{Significance of Indian Transport System}

Following points gives us information about how the transport facility is important for the development of the economy.

\section{Tourism development:}

A good transport system promotes tourism services at domestic as well as international level it help to earn foreign exchange Tourism in India is the largest service industry with a contribution of $6.23 \%$ to the national GDP and $8.78 \%$ of the total employment in India. In 2010 total Foreign Tourist Arrivals (FTA) in India were 5.78 million and India generated about 200

billion US dollars in 2008 and that is expected to increase to US $\$ 375.5$ billion, 2018 at a $9.4 \%$ annual growth rate. Ministry of Tourism is the nodal agency to formulate national policies and programmes for the development and promotion of tourism. In the process, the Ministry consults and collaborates with other stakeholders in the sector including various Central Ministries/agencies, the state governments and union territories and the representatives of the private sector. Concerted efforts are being made to promote new f0mis of tourism such as rural, cruise, medical and eco-tourism. The Ministry of Tourism also maintains the Incredible India campaign. In 2011, total Foreign
Tourist Arrivals (FTA) in India were 6.18 million and Foreign Exchange Earnings stood at US\$ 16.691 billion (Global rank-17) up $17.6 \%$ from previous year figure of US\$ 14.193 billion (5.58 million FTAs in 2010). India's Foreign Exchange earnings grew by an astonishing $14.1 \%$ (CAGR) during 2001-10 out-pacing global average $7.7 \%$.

\section{For The Development Of Foreign Trade}

For the expansion of trade good network of transport system requires i.e why Govt, of India has been spending huge amount of money for the development of entire transport facility. Now a days it enabled our country to export not only light weighted goods but also bulky goods to the rest of the world. Due to this our external earnings has been increasing day by day whole credit for this is goes to transport system.

\section{Sectoral Linkages}

Transport system is essential for linking agriculture, Industry, \& service centre, it helps in developing input, output networks, in various sectors it means that whatever a particular sector needs that gets through transport system because of this the entire picture of every sector has been changing day by day.

\section{For The Development Of Automobile Industry}

India emerged as Asia's fourth largest exporter of passenger cars, behind Japan, South Korea, and Thailand. In 2010, India beat Thailand to become Asia's third largest exporter of passenger cars. As of 2010, India is home to 40 million passenger vehicles. More than 3.7 million automotive vehicles were produced in India in 2010 (an increase of 33.9\%), making the country the second (after China) fastest growing automobile market in the world. According to the Society of Indian Automobile Manufacturers, annual vehicle sales are projected to increase to 5 million by 2015 and more than 9 million by 2020 . By 2050, the country is expected to top the world in car volumes with approximately 611 million vehicles on the nation's roads. It is happening only because of transportation system.

\section{To Establish Better Relations with the World}

Economic growth of every country depends upon numbers of factors among these quality relations with neighboring countries $\&$ rest of the country is important factor. To establish better relations transport facilities plays vital role i.e why up to some extent we are successful to establish better relations with Pakistan, Bangladesh, Bhutan, Nepal, Srilanka \& the rest of the world with the help of road, rail, water, air transport facility.

\section{Reduces Regional Imbalances}

Different regions are connected by means of transport it leads to economic, social, \& cultural development of back word regions, which reduces regional imbalances. In India states like Bihar, Orissa, Jharkhand, Tripura, Meghalaya, Assam, Uttaranchal are improving their economic growth rate by connecting themselves to developed states \& regions with the different mode of transport. 


\section{Other Significance}

Transport is also important for rapid industrial development, for creation of employ-ment to overcoming scarcity, to create place utility etc.

\section{India's Road}

\section{Development and growth potential}

For a country, particularly of India's size, an efficient road network is mandatory for national integration, for socioeconomic development and to sustain Indian economic growth. Therefore, in the last few decades the transport sector transformed increasingly from rail-dominated to road-dominated.

Although transport services by rail also exist in the metropolises, they play no major role in Indian passenger mobility.16 Thus the roadways already hold an estimated share of $80 \%$ of the demand on land transport. Furthermore, the demand in passenger transport by road, recorded an immense growth since the $1980 \mathrm{~s}$ as it increased at a rate of $8 \%$ per year. 17 This points to the growing presence and variety of transport vehicles.

\section{Growth of vehicles}

The annual growth of motorized vehicles during the last decade was around 10\%. Compared to 21.7 million vehicles in 1991 the number of vehicles nearly trebled in 2001 with 55 million.

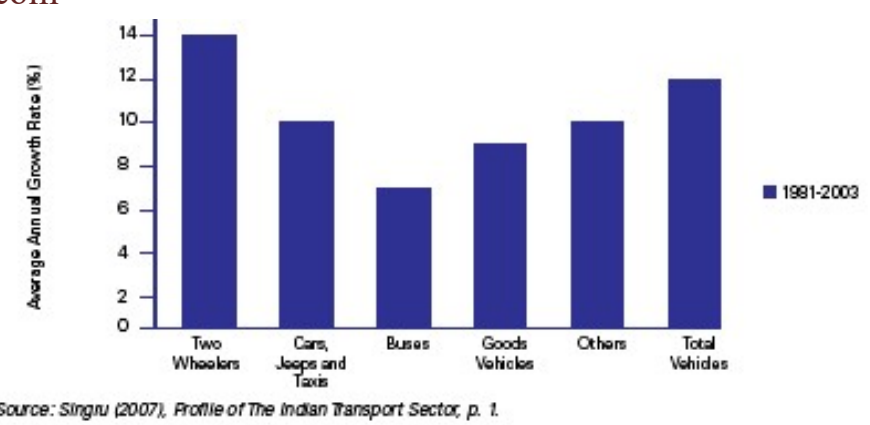

Above all, the two-wheelers have a high growth rate which constitutes to over a half of total vehicles. Furthermore, twowheelers and cars account for example, more than $88 \%$ in Hyderabad and $91 \%$ in Kanpur. However, the share of buses when compared to the two-wheelers is insignificant. They constitute merely $0.5 \%$ in each of the cities mentioned above.

Along with the vehicular growth, the freight transport also increased over the years with an annual growth rate of about $12 \% .21$ This can be attributed to the rise in container traffic, as exports and imports increased $22-25 \%$ per year. Additionally, while traditional, non-mechanized means of transport, e.g. elephants and camels, are still common, an increasing number of vehicles, especially trucks, lead to increasing congestion

\section{References}

1. Indian economy-Datt Sundharam

2. Indian economy - Desai Bhalerao

3. General Economics - The Instituteof Chartered accountants of India

4. General Economics - Arpita Ghosh

5. Economics Times Now

6. Economic \& Political Weekly

7. www.google.com 